\title{
Assessment of Deoxynivalenol in Wheat, Corn and Its Products and Estimation of Dietary Intake
}

\author{
Shahzad Zafar Iqbal ${ }^{1, * \mathbb{C}}$, Sunusi Usman ${ }^{2}$, Ahmad Faizal Abdull Razis $2,3, * \mathbb{C}$, \\ Nada Basheir Ali ${ }^{3}$, Tahmina Saif ${ }^{1}$ and Muhammad Rafique Asi ${ }^{4}$ \\ 1 Department of Applied Chemistry, Government College University Faisalabad, Faisalabad 38000, Pakistan; \\ tahminasaif27@gmail.com \\ 2 Institute of Bioscience, Universiti Putra Malaysia, 43400 UPM Serdang, Selangor, Malaysia; \\ usunusi.bch@buk.edu.ng \\ 3 Department of Food Science, Faculty of Food Science and Technology, Universiti Putra Malaysia, \\ 43400 UPM Serdang, Selangor, Malaysia; nada44basher@gmail.com \\ 4 Plant Production Division, NIAB, Faisalabad 38000, Pakistan; mrasi@niab.edu.pk \\ * Correspondence: shahzad10542005@yahoo.com (S.Z.I.); madfaizal@upm.edu.my (A.F.A.R.)
}

Received: 5 June 2020; Accepted: 9 July 2020; Published: 3 August 2020

\begin{abstract}
The main goal of the present research was to explore the seasonal variation of deoxynivalenol (DON) in wheat, corn, and their products, collected during 2018-2019. Samples of 449 of wheat and products and 270 samples of corn and their products were examined using reverse-phase liquid chromatography with a UV detector. The findings of the present work showed that $104(44.8 \%)$ samples of wheat and products from the summer season, and 91 (41.9\%) samples from winter season were contaminated with DON (concentration limit of detections (LOD) to $2145 \mu \mathrm{g} / \mathrm{kg}$ and LOD to $2050 \mu \mathrm{g} / \mathrm{kg}$ ), from summer and winter seasons, respectively. In corn and products, 87 (61.2\%) samples from summer and 57 (44.5\%) samples from winter season were polluted with DON with levels ranging from LOD to $2967 \mu \mathrm{g} / \mathrm{kg}$ and LOD to $2490 \mu \mathrm{g} / \mathrm{kg}$, from the summer and winter season, respectively. The highest dietary intake of DON was determined in wheat flour $8.84 \mu \mathrm{g} / \mathrm{kg}$ body weight/day from the summer season, and $7.21 \mu \mathrm{g} / \mathrm{kg}$ body weight/day from the winter season. The findings of the work argued the need to implement stringent guidelines and create awareness among farmers, stakeholders, and traders of the harmful effect of DON. It is mostly observed that cereal crops are transported and stockpiled in jute bags, which may absorb moisture from the environment and produce favorable conditions for fungal growth. Therefore, these crops must store in polyethylene bags during transportation and storage, and moisture should be controlled. It is highly desirable to use those varieties that are more resistant to fungi attack. Humidity and moisture levels need to be controlled during storage and transportation.
\end{abstract}

Keywords: DON; wheat; corn; dietary estimation; wheat flour; corn flour

\section{Introduction}

Cereal plays a vital role in human health and wellbeing. Worldwide, cereals are the most important source of energy, and in developed countries, about $30 \%$ of daily calories are derived from cereals, compared to 60 to $80 \%$ calories in developing countries [1]. Pakistan is placed seventh in wheat production (25.07 million tons), 10th in rice production (10.8 million tons) and produces 6.31 million tons of corn [2]. In Pakistan, wheat, rice, and corn are the main staple food crops. Pakistan has extreme weather conditions, due to its presence in the subtropical region. Furthermore, unseasonal rains, monsoons rains, and flash floods are the main factors that provide favorable conditions for the proliferation of fungi in food and food products [3]. The use of traditional cultivation practices 
and unawareness of good harvesting and storage practices are other main factors that provide fungal attacks in crops along the food chain [4].

Mycotoxins are an important class of food toxins, and it is classified as naturally occurring secondary metabolites [5]. The fungi such as Fusarium, Aspergillus, and Penicillium are recognized as major producer of mycotoxins [6,7]. The diversity and variation in mycotoxins could be imagined, because 450 different types of structure of such toxins are identified and classified [8]. The most studied mycotoxins are aflatoxins, ochratoxin A, deoxynivalenol, zearalenone, and fumonisin, due to their toxic nature and adverse effects on food quality and safety [9]. The deoxynivalenol (DON) mycotoxin is also known as vomitoxin is closely related to trichothecenes [10]. The fungi, such as Fusarium culmorum and Fusarium graminearum are mainly responsible for producing this type of mycotoxin (deoxynivalenol) [11]. The studies have shown that at the molecular level, it binds to the ribosome and inhibiting protein synthesis and thus disrupts normal cell function [12]. The low doses of DON exert toxic effects, including immune dysfunction and growth impairment. However, lethal dose exposure can lead to leukocytosis, hemorrhage, diarrhea, endotoxemia, and shock-like death [13].

In order to avoid the health hazard in the local population, strict regulations are imposed for DON in wheat and wheat products used for the consumption of humans and animals. The permissible limit of $2 \mathrm{mg} / \mathrm{kg}$ of DON in raw wheat, barley, and maize has been implemented by the Codex Alimentarius Commission (CAC). In contrast, the level of $2000 \mu \mathrm{g} / \mathrm{kg}$ has been established by the European Union for different types of unprocessed wheat and oat for different populations. Similarly, there is a permissible legal limit of $1000 \mu \mathrm{g} / \mathrm{kg}$ for raw or those cereals which would be unprocessed, however, a limit of $750 \mu \mathrm{g} / \mathrm{kg}$ for those foodstuffs intended for consumers and dry pasta and $200 \mu \mathrm{g} / \mathrm{kg}$ for snacks and breakfast cereal proposed for the consumption of baby food [14].

In Pakistan, wheat is mostly used to prepare bread, and a variety of traditional and culturally flatbread are famous and prepared in a hot clay oven known as "tandoor," which is common throughout rural and urban areas of Pakistan. The country's wheat consumption per capita was $124 \mathrm{~kg}$ per person per year, and $72 \%$ of calorie intake comes from wheat flour, one of the highest in the world [15]. The high incidence of some other mycotoxins in cereal crops from our previous reports, i.e., $30 \%$ samples of wheat products were found to be contaminated with aflatoxins, ranging from limit of detections (LOD) to $69.6 \mu \mathrm{g} / \mathrm{kg}$, and 31\% samples of wheat products were found to be contaminated with zearalenone ranging from LOD to $69.8 \mu \mathrm{g} / \mathrm{kg}$ [16]. In another study $52 \%$ cereal products were found to be contaminated with aflatoxins with concentration ranging from LOD to $9.95 \mu \mathrm{g} / \mathrm{kg}, 50 \%$ cereal products were found to be contaminated with ochratoxin A (LOD to $9.60 \mu \mathrm{g} / \mathrm{kg}$ ), and 56\% samples of cereal products were found to be contaminated with zearalenone (LOD to $110.45 \mu \mathrm{g} / \mathrm{kg}$ ) [17]. It is worth mentioning that we have studied the incidences of AFs, OTA, ZEN in cereals and, recently, fumonisin $B_{1}$ in wheat and barley [18]. Therefore, the current research was planned to investigate the presence of DON in most staple food crops of Pakistan, i.e., wheat and corn. The undertaken research was focused on:

(1) Examining the amount of DON in wheat, corn and their products from summer and winter seasons;

(2) Relating the concentrations of DON with EU recommended limits;

(3) Estimating the dietary intake of DON in wheat and corn products.

A few reports are present on the occurrence of DON in wheat or corn products from Punjab, Pakistan $[19,20]$ and from Turkey [21]. The findings of the present work will help to generate data and, thus, help law enforcement agencies to establish strict regulations for this toxin.

\section{Materials and Methods}

\subsection{Samples}

The 449 samples of wheat and products (wheat flour, semolina, porridge, wheat bread) (232 from the summer season, and 217 from winter season) and 270 samples of corn and products (corn flour, 
cornflakes, boiled corn, corn bread) (142 samples from the summer season and 128 samples from winter season) were collected from various shops, supermarkets and stores of the central cities of Punjab (Lahore, Faisalabad, Jhang and Shorkoat), Pakistan, during December 2017 to June 2018. The samples of wheat, corn and their products were purchased randomly. The summer season is composed from May to August, and the winter season is from November to January. The $1 \mathrm{~kg}$ of sample size of each crop and processed food was maintained. The samples not in ground form were grounded using grinding mill (Retsch, ZM 200, Haan, Düsseldorf, Germany). The samples were taken in polyethylene plastic bags and stored in the freezer at $-20{ }^{\circ} \mathrm{C}$, until further analysis.

\subsection{Chemicals and Reagents}

The regents like polyethylene glycol 8000 (PEG), high purity acetonitrile, and methanol ( $\geq 98 \%$ purity), were obtained from Sigma-Aldrich (Sigma-Aldrich, Lyon, France), however, the standard of DON (100 mg/mL in ACN), were purchased from Sigma Aldrich (Saint-Louis, MO, USA). The linearity curve was constructed by making different levels of DON, i.e., 200, 400, 600, 800, 1600, 2000, and $2600 \mu \mathrm{g} / \mathrm{L}$ in acetonitrile, and each vial was labeled and stored in an appropriate place in refrigerator at $-20{ }^{\circ} \mathrm{C}$. In the undertaken study, other chemicals and reagents used were of high purity.

\subsection{Extraction of DON and HPLC Conditions}

DON was extracted from cereal products following the method as documented by [22]. Briefly, in $20 \mathrm{~mL}$ ultra-pure water, a $5 \mathrm{~g}$ sample was homogenized in $50 \mathrm{~mL}$ Teflon tubes and centrifuged at $6500 \mathrm{rpm}$ for $1 \mathrm{~min}$ by adding $1 \mathrm{~g}$ of PEG. Then, $200 \mathrm{~mL}$ water was applied on dry bread to regain its moisture content, before it was homogenized for $5 \mathrm{mint}$ at room temperature at $8000 \mathrm{rpm}$. The extract was filtered with filter paper after centrifugation, and $5 \mathrm{~mL}$ of the filtrate was passed to the immunoaffinity column (IAC) (VICAM, Watertown, MA, USA) for DON. After that, the column was washed twice with $10 \mathrm{~mL}$ purified water each time, and $1 \mathrm{~mL}$ pure methanol was used to extract DON from the IAC column. Then, the elute was diluted with purified water two times, i.e., $0.5 \mathrm{~mL}$ elute: $0.5 \mathrm{~mL}$ water. Finally, the diluted extract was subjected to HPLC analysis, before passing it through $0.22 \mu \mathrm{m}$ nylon syringe filters. The HPLC system (Shimadzu, Kyoto, Japan) had a separation C18 Supelco column $(4.6 \times 250 \times 5 \mathrm{~mm})$ (Discovery HS, Bellefonte, PA, USA) and a UV detector (RF-530). The mobile phase has consisted of a mixture of $30 \%$ methanol and $70 \%$ of water. The $1.2 \mathrm{~mL} / \mathrm{min}$ of flow rate was set off the mobile phase. The $50 \mu \mathrm{L}$ samples were injected into the column for analysis, the column temperature was maintained at $30{ }^{\circ} \mathrm{C}$, and the detection wavelength was $218 \mathrm{~nm}$.

\subsection{Dietary Intake Evaluation}

The analysis of the dietary intake of DON in cereal products, a previous method Alim et al. [17], was followed. The consumption data was gathered by providing a food frequency questionnaire around 500 individuals and asked them about the cereal products they used in the last 2 weeks. The questionnaire is completed in every respect by memorizing the cereal products used, its quantity, frequency, and other food ingredients. The weight of normal cup, bowl, and average size plate was also mentioned, and based on this information, the exact weight of food consumed was estimated. The average body weight of and individual was proposed at $60 \mathrm{~kg}$. The dietary intake was estimated as

$$
\text { Dietary Intake of Don }\left(\mathrm{ng} \mathrm{kg}^{-1} \mathrm{day}^{-1}\right)=\frac{\text { Consumption of cereals }(g) x \text { Mean level of DON }\left(\mu \frac{g}{\mathrm{~kg}}\right)}{\text { Average weight of individual }(\mathrm{kg})}
$$

\subsection{Method Validation}

The HPLC quality control parameters like linearity, precision, limit of detections (LOD), limit of quantifications (LOQ), repeatability, and reproducibility of DON were calculated. The LOD was determined as 3:1 of signal to-noise ratio and LOQ was calculated as 10:1 signal-to-noise ratio [23]. 
The repeatability and reproducibility of the method were determined by spiking 2 different amounts of DON (5 replicate each) in a sample on the same day. Repeatability and reproducibility described in current research $\mathrm{R}^{2} \geq 0.998$, which shown good linear function. The recoveries were determined by adding a known level of DON, i.e., 100, 200, 400, 800, 1600, and $2000 \mu \mathrm{g} \mathrm{kg}^{-1}$ were added in matrix samples. The recoveries ranged between 80.8 to $92.2 \%$ with relative standard deviation from 9 to $27 \%$, as represented in Table 1.

Table 1. Recovery percentage of deoxynivalenol (DON) in wheat, corn, wheat flour and corn flour samples.

\begin{tabular}{ccccccccc}
\hline $\begin{array}{c}\text { Don } \\
\text { Level }\end{array}$ & \multicolumn{2}{c}{ Wheat } & \multicolumn{2}{c}{ Wheat Flour } & \multicolumn{2}{c}{ Corn } & \multicolumn{2}{c}{ Corn Flour } \\
\hline $\boldsymbol{\mu g} / \mathbf{K g}$ & $\begin{array}{c}\text { Recovery } \\
\mathbf{( \% )}\end{array}$ & $\begin{array}{c}\text { RSD } \\
\mathbf{( \% )}\end{array}$ & $\begin{array}{c}\text { Recovery } \\
\mathbf{( \% )}\end{array}$ & $\begin{array}{c}\text { RSD } \\
\mathbf{( \% )}\end{array}$ & $\begin{array}{c}\text { Recovery } \\
\mathbf{( \% )}\end{array}$ & $\begin{array}{c}\text { RSD } \\
\mathbf{( \% )}\end{array}$ & $\begin{array}{c}\text { Recovery } \\
\mathbf{( \% )}\end{array}$ & $\begin{array}{c}\text { RSD } \\
\mathbf{( \% )}\end{array}$ \\
\hline 100 & 82.5 & 14 & 80.8 & 9 & 87.4 & 10 & 88.9 & 13 \\
200 & 87.8 & 18 & 85.4 & 12 & 89.8 & 16 & 90.0 & 15 \\
400 & 89.0 & 19 & 84.7 & 19 & 92.6 & 20 & 86.7 & 10 \\
800 & 90.0 & 10 & 88.9 & 10 & 88.9 & 25 & 85.6 & 18 \\
1600 & 87.8 & 23 & 84.1 & 19 & 86.7 & 25 & 86.7 & 20 \\
2000 & 89.0 & 26 & 82.0 & 21 & 89.5 & 27 & 83.5 & 27 \\
\hline
\end{tabular}

$\mathrm{RSD}=$ relative standard deviation; $\mathrm{LOD}=50 \mu \mathrm{g} / \mathrm{kg} ; \mathrm{LOQ}=100 \mu \mathrm{g} / \mathrm{kg}$.

\subsection{Statistical Analysis}

The analysis of DON were statistically observed and represented as average levels and standard deviations. However, the samples below the detection limits, but greater than zero were substituted with $\frac{L D}{\sqrt{2}}$, and the $\left(\mathrm{R}^{2}\right)$ was analyzed using linear regression/correlation analysis. The significant difference in the levels of DON among different seasons was calculated using a one-way analysis of variance (SPSS, IBM, Statistics 21).

\section{Results and Discussion}

\subsection{Method Validation}

The recoveries of DON in wheat, corn, wheat and corn flour are represented in Table 1, and the recoveries were greater than $80 \%$, as recommended by (AOAC method 991.31). The recovery analysis were done in different mycotoxins with concentrations of 6.5 and $13 \mathrm{ng} / \mathrm{g}$ for AFs, 10 and $20 \mathrm{ng} / \mathrm{g}$ for OTA, and 100 and $200 \mathrm{ng} / \mathrm{g}$ for ZEA were between 74.1\% and 104.8\%, and the relative standard deviation (RSD) values were in the range of 2.4 to $11.9 \%$ [24]. Furthermore, the recoveries were within the range of 70-110\%, as required by European Commission regulation 401/2006 [25], hence, they were considered satisfactory. However, the recoveries of corn were comparatively greater, as compared to the wheat samples. This might be due to the high content of polar components in corn matrix, which dissolve polar solvent more easily, and further investigation in this regard is highly needed. Form China, the detection of LOD and LOQ of DON in wheat grain were $0.5 \mu \mathrm{g} / \mathrm{kg}$, and $1.5 \mu \mathrm{g} / \mathrm{kg}$, much lower compared to current study [23]. The lower LOD and LOQ were determined in wheat of DON, i.e., 11.3 and $37.6 \mu \mathrm{g} / \mathrm{kg}$, respectively [26]. Thus, LOD and LOQ are two quantities that have accuracies that depend on the sensitivity of the device used [27].

\subsection{DON Incidence in Wheat and What Products}

The incidence and occurrence levels of DON were investigated in 232 samples of wheat and products from the summer season and in 217 samples from the winter season, as represented in Table 2. The highest average amount of DON was present in wheat flour, i.e., $1325.5 \pm 24.7 \mu \mathrm{g} / \mathrm{kg}$ samples from the summer season and the lowest mean level was found in wheat porridge $(934.1 \pm 19.2 \mu \mathrm{g} / \mathrm{kg}) \mathrm{from}$ 
the summer season. However, the highest mean levels of DON from the winter season were $1080.7 \pm$ $30.5 \mu \mathrm{g} / \mathrm{kg}$ in wheat flour samples. The results have shown that 104 (44.8\%) samples out of 232 from the summer season were found to be contaminated with DON in wheat and wheat products, and 91 (41.9\%) out of 217 samples were found to be positive with DON from the winter season. The results of DON in summer and winter samples of wheat and wheat products were statistically significant at $\alpha$ 0.05 , except in wheat (type 1) samples, which were nonsignificant at $\alpha 0.05$. The samples were $54(23 \%)$ from summer, and 20 (9.2\%) samples from winter of wheat, and wheat products had levels of DON higher than EU's recommended limits, as shown in Figure 1.

Table 2. Incidence and occurrence of DON in wheat and products collected during summer and winter seasons from different cities of Punjab, Pakistan.

\begin{tabular}{|c|c|c|c|c|c|c|c|c|}
\hline \multirow{3}{*}{$\begin{array}{c}\text { Samples } \\
\text { Type }\end{array}$} & \multicolumn{4}{|c|}{ Summer } & \multicolumn{4}{|c|}{ Winter } \\
\hline & Samples & Positive & Mean & Range & Samples & Positive & Mean & Range \\
\hline & $n$ & $n(\%)$ & $\begin{array}{l}\mu \mathrm{g} / \mathrm{kg} \pm \\
\text { S.D }\end{array}$ & $\mu \mathrm{g} / \mathrm{kg}$ & $n$ & $n(\%)$ & $\begin{array}{c}\mu \mathrm{g} / \mathrm{kg} \pm \\
\text { S.D }\end{array}$ & $\mu \mathrm{g} / \mathrm{kg}$ \\
\hline $\begin{array}{l}\text { Wheat (type } \\
\text { 1) }\end{array}$ & 34 & $13(38.2)$ & $\begin{array}{c}1083.5 \pm \\
15.2^{\mathrm{a}}\end{array}$ & LOD-2145 & 25 & $11(44.0)$ & $\begin{array}{c}1020.8 \pm \\
21.6^{\mathrm{a}}\end{array}$ & LOD-1945 \\
\hline $\begin{array}{l}\text { Wheat (type } \\
\text { 2) }\end{array}$ & 40 & $21(52.5)$ & $\begin{array}{c}945.1^{ \pm} \\
18.9^{\mathrm{b}}\end{array}$ & LOD-2021 & 40 & $15(37.5)$ & $\begin{array}{l}790 \pm \\
20.9^{c}\end{array}$ & LOD-2050 \\
\hline Wheat flour & 38 & $21(55.2)$ & $\begin{array}{c}1325.5^{ \pm} \\
24.7^{\mathrm{c}}\end{array}$ & LOD-1890 & 38 & 15 (39.5) & $\begin{array}{c}1080.7 \pm \\
30.5^{\mathrm{a}}\end{array}$ & LOD-1500 \\
\hline Semolina & 42 & $18(42.8)$ & $\begin{array}{c}1026.4 \pm \\
17.3^{a}\end{array}$ & LOD-1459 & 41 & $18(43.9)$ & $\begin{array}{l}750.7 \pm \\
25.6^{\mathrm{b}}\end{array}$ & LOD-1130 \\
\hline $\begin{array}{l}\text { Wheat } \\
\text { porridge }\end{array}$ & 49 & $20(40.8)$ & $\begin{array}{c}934.1 \\
\pm 19.2^{\mathrm{b}}\end{array}$ & LOD-980 & 46 & 19 (41.3) & $\begin{array}{c}690.5^{ \pm} \\
19.6^{\mathrm{c}}\end{array}$ & LOD-950 \\
\hline Wheat bread & 29 & $11(37.9)$ & $\begin{array}{l}990.4 \pm \\
21.8^{\mathrm{b}}\end{array}$ & LOD-1120 & 27 & $13(48.1)$ & $\begin{array}{c}705.6 \pm \\
23.7^{\mathrm{c}}\end{array}$ & LOD-1080 \\
\hline Total & 232 & $104(44.8)$ & & LOD-2145 & 217 & $91(41.9)$ & & L0D-2050 \\
\hline
\end{tabular}

The data in parenthesis represents the percentage to total analyzed samples. LOD = limit of detection (LOD 50 $\mu \mathrm{g} / \mathrm{kg}$ ) The mean levels with different English alphabetic within the row indicated statistically significant results $(p$ $\leq 0.05$ ). Type 1 and Type 2 represents different varieties.

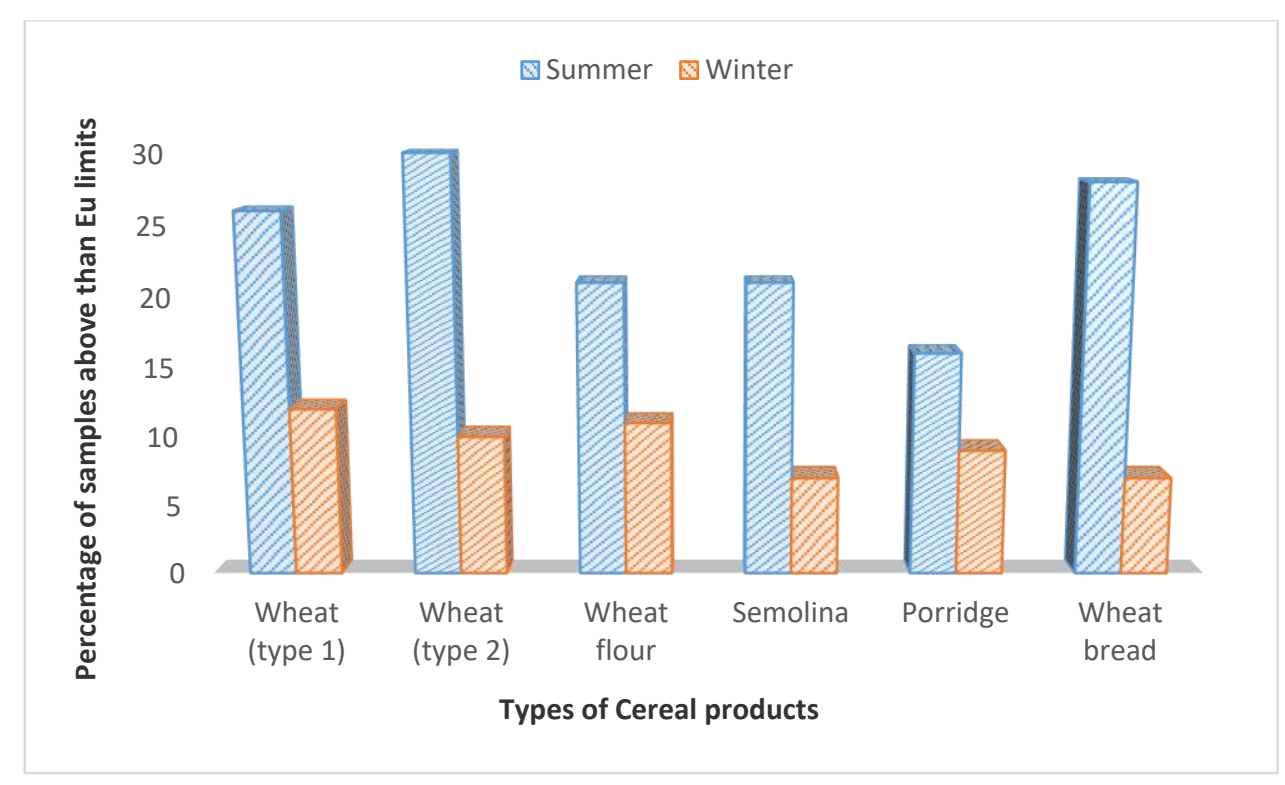

Figure 1. Comparision of sample of wheat and products having levels of DON higher than EU limits.

Previous studies have shown very high incidence as well as occurrence levels of DON in wheat samples. Bryla et al. [28] from Poland has documented that $100 \%$ of wheat samples were found to be positive, with DON with a mean level of $770.7 \mu \mathrm{g} / \mathrm{kg}$, ranging from 82 to $2975 \mu \mathrm{g} / \mathrm{kg}$. In another 
study from China, $87.5 \%$ samples of wheat and wheat products were found to be positive, with DON with a range of 12.5 to $1920.4 \mu \mathrm{g} / \mathrm{kg}, 100 \%$ samples of wheat flour, the level of DON was 51.6 to $1308.9 \mu \mathrm{g} / \mathrm{kg}$, and in Chinese steamed bread, the mean level was 54.5-845.4 $\mu \mathrm{g} / \mathrm{kg}$ [11]. Palacios et al. [7], from Argentina, has shown that DON was found in all samples of wheat with concentrations varying between LOD $(50 \mu \mathrm{g} / \mathrm{kg})$ to $9480 \mu \mathrm{g} / \mathrm{kg}$. Liu et al. [29], from China, have revealed that out of 672 samples of wheat, $91.5 \%$ of samples were found to be positive with DON, at levels ranging from 2.4 to $1130 \mu \mathrm{g} / \mathrm{kg}$. In another study, Ji et al. [30] have detected the levels of DON in 180 wheat samples from China, with levels ranging from 14.52 to $41157.13 \mu \mathrm{g} / \mathrm{kg}$ (mean level of $488.02 \mu \mathrm{g} / \mathrm{kg}$ ). The hot and humid environmental conditions might explain the high incidence levels of DON in wheat and wheat products samples from the summer season during summer in Pakistan. The levels of toxins during seasons depend on the variation in the structure of toxins during cropping seasons [31]. The crop of wheat is harvested in summer season mostly in May and June, which might increase the probabilities of fungal attack during pre-harvest, or postharvest, or during the storage of mycotoxins production. The other factors of a high incidence of DON in wheat and wheat products might be the use of those wheat varieties which were sensitive for fungal attack, old traditional farming practices, no crop rotation, and no-till farming. Furthermore, in villages, people store wheat or corn in mud bins, which may absorb moisture from the environment and cause fungal attacks [16]. Furthermore, temperature, humidity, sunlight effect, and survival of mycotoxigenic fungi to host are essential factors [32].

\subsection{Corn and Products}

The incidence and occurrence levels of DON were investigated in 142 samples of corn and products from the summer and 128 samples from winter seasons, as revealed in Table 3. The results have documented that $87(61.2 \%)$ samples out of 142 were found positive from the summer season, and 57 $(44.5 \%)$ samples from the winter season were found contaminated with DON. The highest mean level of $1434.8 \pm 25.5 \mu \mathrm{g} / \mathrm{kg}$ in corn flour samples from summer season was found, and the lowest mean level of DON was found in cornbread $620.8 \pm 17.8 \mu \mathrm{g} / \mathrm{kg}$, from the winter season. The incidence levels of DON in corn and corn products from the summer season were statistically significant from the samples of winter season ( $\alpha 0.05$ ) except cornbread samples. The samples of corn and corn products having levels of DON higher than the recommended limits of the EU are compared in Figure 2.

Table 3. Incidence and occurrence of DON in corn and products from summer and winter seasons from different cities of Punjab, Pakistan.

\begin{tabular}{|c|c|c|c|c|c|c|c|c|}
\hline \multirow{3}{*}{$\begin{array}{l}\text { Samples } \\
\text { Type }\end{array}$} & \multicolumn{4}{|c|}{ Winter } & \multicolumn{4}{|c|}{ Summer } \\
\hline & Samples & Positive & $\begin{array}{c}\text { Mean } \pm \\
\text { S.D }\end{array}$ & Range & Samples & Positive & $\begin{array}{c}\text { Mean } \pm \\
\text { S.D }\end{array}$ & Range \\
\hline & $n$ & $n(\%)$ & $\mu \mathrm{g} / \mathrm{kg}$ & $\mu \mathrm{g} / \mathrm{kg}$ & $n$ & $n(\%)$ & $\mu \mathrm{g} / \mathrm{kg}$ & $\mu \mathrm{g} / \mathrm{kg}$ \\
\hline $\begin{array}{c}\text { Corn (type } \\
1)\end{array}$ & 25 & $14(56.0)$ & $\begin{array}{c}1345.7 \pm \\
22.3^{\mathrm{a}}\end{array}$ & LOD-2967 & 20 & $9(45.5)$ & $\begin{array}{c}978.7 \pm \\
15.6^{\mathrm{a}}\end{array}$ & LOD-2490 \\
\hline $\begin{array}{c}\text { Corn (type } \\
\text { 2) }\end{array}$ & 26 & $16(61.5)$ & $\begin{array}{c}998.2^{ \pm} \\
11.2^{\mathrm{b}}\end{array}$ & LOD-2234 & 25 & $11(44.0)$ & $\begin{array}{c}680.6^{ \pm} \\
11.8^{\mathrm{c}}\end{array}$ & LOD-2650 \\
\hline Corn flour & 25 & $18(72.0)$ & $\begin{array}{c}1434.8 \pm \\
25.5^{\mathrm{a}}\end{array}$ & LOD-2434 & 26 & $12(46.1)$ & $\begin{array}{c}860.7 \pm \\
13.9^{\mathrm{b}}\end{array}$ & LOD-1460 \\
\hline Cornflakes & 24 & $12(50.0)$ & $\begin{array}{c}1245.9 \pm \\
18.5^{\mathrm{a}}\end{array}$ & LOD-1534 & 22 & $10(45.4)$ & $\begin{array}{c}910.4^{ \pm} \\
23.7^{\mathrm{b}}\end{array}$ & LOD-1090 \\
\hline Boiled corn & 22 & $13(59.5)$ & $\begin{array}{r}1067.5 \\
\pm 14.1 \mathrm{~b}\end{array}$ & LOD-920 & 20 & $9(45.0)$ & $\begin{array}{c}850.9 \pm \\
15.7^{\mathrm{d}}\end{array}$ & LOD-980 \\
\hline Corn bread & 20 & $14(70.0)$ & $\begin{array}{l}640.5^{ \pm} \\
11.3^{c}\end{array}$ & LOD-1320 & 15 & $6(40.0)$ & $\begin{array}{l}620.8 \pm \\
17.80^{c}\end{array}$ & LOD-1250 \\
\hline Total & 142 & 87 (61.2) & & LOD-2967 & 128 & $57(44.5)$ & & LOD-2490 \\
\hline
\end{tabular}

The data in parenthesis represents the percentage to total analyzed samples. LOD = limit of detection (LOD 50 $\mu \mathrm{g} / \mathrm{kg}$ ). The mean levels with different English alphabetic within the row indicated statistically significant results $(p$ $\leq$ 0.05). Type 1 and Type 2 represents different varieties. 


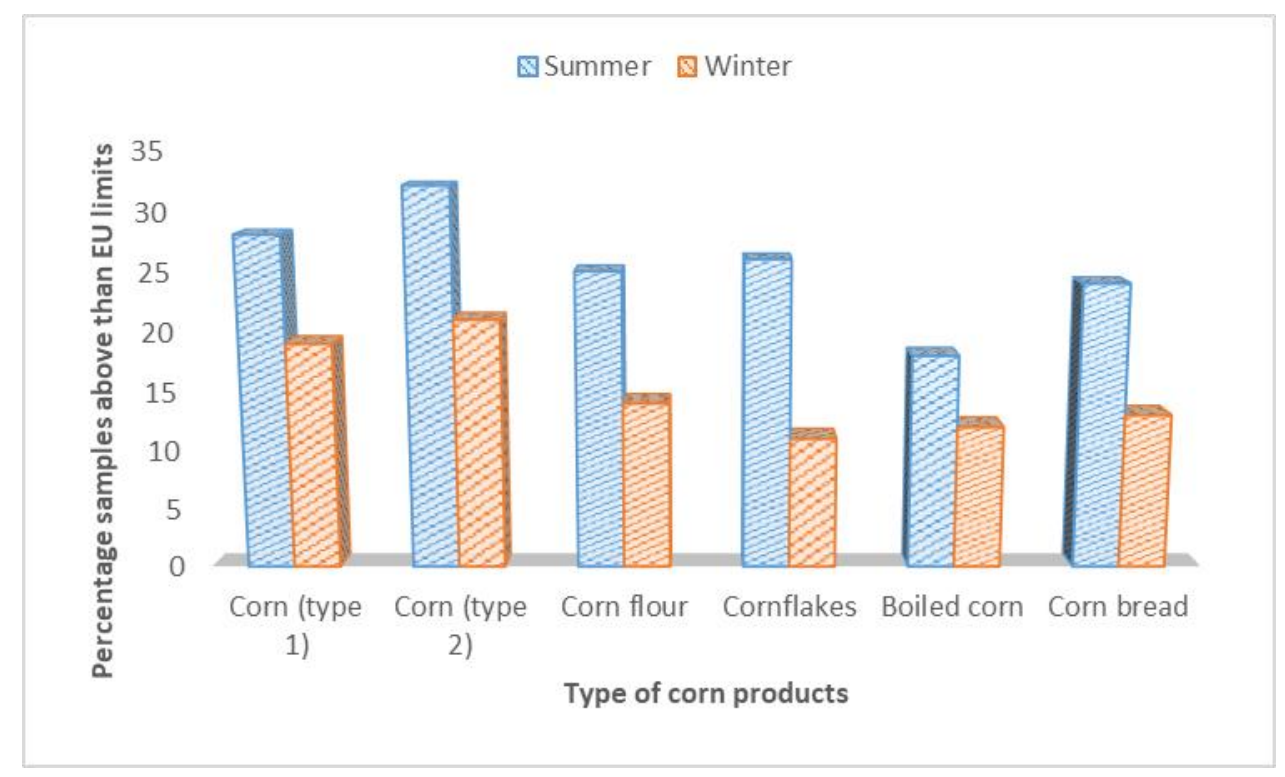

Figure 2. Comparison of sample of corn and products having levels of DON higher than EU limits.

The levels of DON contamination (ranged, LOD to $2967 \mu \mathrm{g} / \mathrm{kg}$ in summer and LOD to $2490 \mu \mathrm{g} / \mathrm{kg}$ in winter season) found in the corn and corn products are much higher in undertaken research. In other studies, the levels of 57 to $825 \mu \mathrm{g} / \mathrm{kg}$ in corn flour samples from Tanzania [33], and 43 to $435 \mu \mathrm{g} / \mathrm{kg}$ stated for corn in Cameroon [34] and in Italy, where levels of 1 to $930 \mu \mathrm{g} / \mathrm{kg}$ are described in processed food products in the retail market [35]. The results are comparable to the levels (up to $1250 \mu \mathrm{g} / \mathrm{kg}$ ) that were documented in those processed food used in other countries [30]. Higher incidences have been documented by Ji et al. [11] from China, where 73.3\% of corn flour samples were contaminated with DON, with a range of 26.4 to $138.2 \mu \mathrm{g} / \mathrm{kg}$. Kamala et al. [33] from Tanzania, collected corn kernels from 300 household stores, and found that $63 \%$ of samples were contaminated with DON, ranging from 68 to $2196 \mu \mathrm{g} / \mathrm{kg}$, in agreement with the findings of the undertaken research. Similarly, a very high incidence, i.e., $85 \%$ of corn samples, was found to be contaminated with DON in Croatia, with a maximum of $17.92 \mathrm{mg} / \mathrm{kg}(\mu \mathrm{g} / \mathrm{kg})$. The factors like high humidity, high moisture content and high temperature might explain the high levels of DON in corn (Pleadin et al. [36]). Setyabudi et al. [37], from Indonesia, documented that 26 corn based-food products have levels of DON, ranging from 103.4 to $170.3 \mu \mathrm{g} / \mathrm{kg}$ in corn flour, 62.6 to $308.3 \mu \mathrm{g} / \mathrm{kg}$ in extruded corn, 59.9 to $202.1 \mu \mathrm{g} / \mathrm{kg}$ in popcorn, and 67.1 to $348.0 \mu \mathrm{g} / \mathrm{kg}$ fried corn, respectively. Martos et al. [38], from Canada, investigated 15 samples of corn for the occurrence of DON, and 14 samples were found to be positive, with a mean level of $1513.5 \mu \mathrm{g} / \mathrm{kg}$ (ranged from 574 to $4865 \mu \mathrm{g} / \mathrm{kg}$ ). The variation and diversity in the levels of mycotoxins in cereal crops might be due to the origin and the year of harvesting crops [39]. However, fungi proliferation and ultimately, the production of mycotoxins in cereal crops might be the result of climatic and improper storage conditions [3].

\subsection{Dietary Estimation}

The dietary intake of DON in samples of wheat and corn products from summer and winter seasons were investigated and presented in Table 4 . The highest dietary intake of DON was found in wheat flour, i.e., $8.8 \mu \mathrm{g} / \mathrm{day} \mathrm{kg}$ bodyweight from the summer season. The lowest dietary intake was found in semolina, i.e., $1.37 \mu \mathrm{g} /$ day $\mathrm{kg}$ body weight in the summer season. However, the dietary intake level of 7.21 was found in wheat flour samples from the winter season. Raad et al. [40] estimated the dietary intake of DON in breads and toasts was $1052 \mathrm{ng} \mathrm{kg}-1$ body weight day-1 (1.05 $\mu \mathrm{g} / \mathrm{day} \mathrm{kg}$ bodyweight), which is much lower than the dietary intake of the present study. Similarly, a much lower dietary intake was documented by Cano-Sancho et al. [41] in pasta samples, which was 27 to $38 \mathrm{ng} \mathrm{kg}^{-1}$ body weight day ${ }^{-1}$. In another study, the 95th percentile exposure of total DON forms was determined 
in children, from 648 to $1030 \mathrm{ng} / \mathrm{kg}$ bw/day (LB/lower bound/and UB/upper bound), in women from 272 to $490 \mathrm{ng} / \mathrm{kg}$ bw/day, and in men from 362 to $923 \mathrm{ng} / \mathrm{kg}$ bw/day [42]. In Romania, the dietary exposure of DON in wheat-based products for direct human consumption was $669 \mathrm{ng} / \mathrm{kg}$ bw/day (LB), and $690 \mathrm{ng} / \mathrm{kg}$ bw/day (UB) in the adult population [43]. However, in Portugal the mean of daily intake of DON was $53.9 \mathrm{ng} / \mathrm{kg}$ bw/day in children under three years of age, through the consumption of three groups of cereal based products (breakfast cereals, infant cereals and biscuits) [44].

Table 4. Dietary exposure assessment for DON in wheat, corn and products consumed by local population.

\begin{tabular}{|c|c|c|c|c|c|}
\hline \multirow[b]{2}{*}{ Cereal Product } & \multirow[b]{2}{*}{$\begin{array}{l}\text { Per Capita } \\
\text { Consumption }\end{array}$} & \multicolumn{2}{|c|}{ Summer } & \multicolumn{2}{|c|}{ Winter } \\
\hline & & $\begin{array}{c}\text { DON Mean } \\
\text { Level }\end{array}$ & Dietary Intake & $\begin{array}{c}\text { DON Mean } \\
\text { Level }\end{array}$ & Dietary Intake \\
\hline & $\mathrm{g} \mathrm{day}^{-1}$ & $\mathrm{ng} \mathrm{g}^{-1}$ & $\begin{array}{l}\mu \mathrm{g} \text { day }^{-1} \text { kg }^{-1} \\
\text { Bodyweight }\end{array}$ & $\left(\operatorname{ng~g}^{-1}\right)$ & $\begin{array}{c}\mu \mathrm{g} \text { day }^{-1} \mathrm{~kg}^{-1} \\
\text { Bodyweight }\end{array}$ \\
\hline Wheat flour & 400 & 1325.5 & 8.84 & 1080.7 & 7.21 \\
\hline Bread & 400 & 990.4 & 6.61 & 705.6 & 4.71 \\
\hline Semolina & 80 & 1026.4 & 1.37 & 750.7 & 1.01 \\
\hline Porridge & 90 & 934.1 & 1.41 & 690.5 & 1.04 \\
\hline Corn flour & 200 & 1434.8 & 4.78 & 860.7 & 2.87 \\
\hline Bread & 200 & 640.5 & 2.14 & 620.8 & 2.07 \\
\hline Cornflakes & 80 & 1245.9 & 1.66 & 910.4 & 1.24 \\
\hline Boiled corn & 200 & 1067.5 & 3.56 & 850.9 & 2.84 \\
\hline
\end{tabular}

The average weight $=60(\mathrm{~kg})$.

\section{Conclusions}

The incidence and contamination of DON wheat and corn products were observed to be relatively higher, as likened with the permissible allowed limits of the EU. To our best knowledge, very few reports were documented on the estimation of DON in wheat and corn products from Pakistan. The current results will be helpful for food authorities to establish strict regulations for this toxin. The results will also help to create awareness among traders, farmers, and local consumers. It is mostly observed that cereal crops are transported and stockpiled in jute bags, which may absorb moisture from the environment and produce favorable conditions for fungal growth. Therefore, these crops must store in polyethylene bags during transportation and storage, and moisture should be controlled. It is highly desirable to use those varieties which are more resistant to fungi attack. Humidity and moisture levels need to be controlled during storage and transportation.

Author Contributions: The authors S.Z.I. has designed the experiment and involved in writing the major parts of manuscript, the authors A.F.A.R. N.B.A. and S.U. have involved calculations of data and T.S. has conducted and collected samples and M.R.A. conducted experimental work. All authors have read and agreed to the published version of the manuscript.

Funding: The research was funded by Higher Education Commission (grant no: IPFP/HRD/HEC/2011), Islamabad, Pakistan. The APC was funded by Universiti Puta Malaysia.

Acknowledgments: The analytical facilities provided by NIAB, Pakistan was highly appreciated.

Conflicts of Interest: All authors are agreed to publish this article and have no conflict of interests whatsoever.

\section{References}

1. Awika, J.M. Major cereal grains production and use around the world. In Advances in Cereal Science: Implications to Food Processing and Health Promotion; American Chemical Society: Washington, DC, USA, 2011; Volume 1089, pp. 1-13.

2. Available online: http://www.fao.org/faostat/en/\#rankings/countries_by_commodity (accessed on 4 June 2020). 
3. Iqbal, S.Z.; Paterson, R.R.M.; Bhatti, I.A.; Asi, M.R.; Sheikh, M.A.; Bhatti, H.N. Aflatoxin B $_{1}$ in chilies from the Punjab region, Pakistan. Mycotoxin Res. 2010, 26, 205-209. [CrossRef]

4. Villa, P.; Markaki, P. Aflatoxin $B_{1}$ and ochratoxin A in breakfast cereals from Athens market: Occurrence and risk assessment. Food Control 2009, 20, 455-461. [CrossRef]

5. Iqbal, S.Z.; Malik, S.; Asi, M.R.; Jinap, S.; Malik, N. Natural occurrence of patulin in different fruits, juices and smoothies and evaluation of dietary intake. Food Control 2018, 84, 370-374. [CrossRef]

6. Iqbal, S.Z.; Asi, M.R.; Hanif, U.; Zuber, M.; Jinap, S. The presence of aflatoxins and ochratoxin A in rice and rice products; and evaluation of dietary intake. Food Chem. 2016, 210, 135-140. [CrossRef]

7. Palacios, S.A.; Erazo, J.G.; Ciasca, B.; Lattanzio, V.M.T.; Reynoso, M.M.; Farnochi, M.C.; Torres, A.M. Occurrence of deoxynivalenol and deoxynivalenol-3-glucoside in durum wheat from Argentina. Food Chem. 2017, 230, 728-734. [CrossRef]

8. Masood, M.; Iqbal, S.Z.; Asi, M.R.; Malik, N. Natural occurrence of aflatoxins in dry fruits and edible nuts. Food Control 2015, 55, 62-65. [CrossRef]

9. Binder, E.M.; Tan, L.M.; Chin, L.J.; Handl, J.; Richard, J. Worldwide occurrence of mycotoxins in commodities, feeds and feed ingredients. Anim. Feed Sci. Technol. 2007, 137, 265-282. [CrossRef]

10. Martins, M.; Almeida, I.; Marques, M.F.; Guerra, M.M. Fumonisins and deoxynivalenol in corn-based food products in Portugal. Food Chem. Toxicol. 2008, 46, 2585-2587. [CrossRef]

11. Ji, X.; Yang, H.; Wang, J.; Li, R.; Zhao, H.; Xu, J.; Xiao, Y.; Tang, B.; Qian, M. Occurrence of deoxynivalenol $(\mathrm{DON})$ in cereal-based food products marketed through e-commerce stores and an assessment of dietary exposure of Chinese consumers to DON. Food Control 2018, 92, 391-398. [CrossRef]

12. Pestka, J.J.; Smolinski, A.T. Deoxynivalenol: Toxicology and potential effects on humans. J. Toxicol. Environ. Health Part B 2005, 8, 39-69. [CrossRef]

13. Pestka, J.J. Deoxynivalenol: Mechanisms of action, human exposure, and toxicological relevance. Arch. Toxicol. 2010, 84, 663-679. [CrossRef]

14. European Commission. Commission Regulation No. 1881/2006 of 19 December 2006 setting maximum levels for certain contaminants in foodstuffs. Off. Eur. J. Union 2006, 364, 5-24.

15. USDA. Pakistan: Grain and Feed Annual. 2017. Available online: https://apps.fas.usda.gov/newgainapi/api/ report/downloadreportbyfilename?filename=Grain\%20and\%20Feed\%20Annual_Islamabad_Pakistan_4-32017.pdf (accessed on 7 July 2020).

16. Iqbal, S.Z.; Asi, M.R.; Jinap, S.; Rashid, U. Detection of aflatoxins and zearalenone contamination in wheat derived products. Food Control 2014, 35, 223-226. [CrossRef]

17. Alim, M.; Iqbal, S.Z.; Mahmood, Z.; Asi, M.R.; Zikar, H.; Chanda, H.; Malik, N. Survey of mycotoxins in retail market cereals, derived products and dietary assessment. Food Control 2018, 84, 471-477. [CrossRef]

18. Iqbal, S.Z.; Rehman, B.; Jinap, S.; Akram, N.; Ahmad, M.N.; Sanny, M. Assessment of fumonisin $B_{1}$ concentrations in wheat and barley products in the Punjab region of Pakistan. J. Food Prot. 2020. [CrossRef]

19. Khatoon, S.; Hanif, Q.N.; Tahira, I.; Sultana, N.; Sultana, K.; Ayub, N. Natural occurrence of aflatoxins, zearalenone and trichothecenes in maize grown in Pakistan. Pak. J. Bot. 2012, 44, 231-236.

20. Sahar, N.; Ahmed, M.; Parveen, Z.; Ilyas, A.; Bhutto, A. Screening of mycotoxins in wheat, fruits and vegetables grown in Sindh, Pakistan. Pak. J. Bot. 2009, 41, 337-341.

21. Golge, O.; Kabak, B. Occurrence of deoxynivalenol and zearalenone in cereals and cereal products from Turkey. Food Control 2020, 110, 106982. [CrossRef]

22. Li, R.; Wang, X.; Zhou, T.; Yang, D.; Wang, Q.; Zhou, Y. Occurrence of four mycotoxins in cereal and oil products in Yangtze Delta region of China and their food safety risks. Food Control 2014, 35, 117-122. [CrossRef]

23. Zhang, H.; Sun, J.; Zhang, Y.; Lu, M.; Sun, L.; Li, W.; Hu, X.; Wang, B. Retention of deoxynivalenol and its derivatives during storage of wheat grain and flour. Food Control 2016, 65, 177-181. [CrossRef]

24. Rahmani, A.; Jinap, S.; Soleimany, F. Validation of the procedure for the simultaneous determination of aflatoxins ochratoxin A and zearalenone in cereals using HPLC-FLD. Food Addit. Contam. 2010, 27, 1683-1693. [CrossRef] [PubMed]

25. European Commission. Commission Regulation (EC) No 401/2006 of 23 February 2006 laying down the methods of sampling and analysis for the official control of the levels of mycotoxins in foodstuffs. Off. J. Eur. Union 2006, 70, 19-23. 
26. Borras-Vallverdú, B.; Ramos, A.J.; Marín, S.; Sanchis, V.; Rodríguez-Bencomo, J.J. Deoxynivalenol degradation in wheat kernels by exposition to ammonia vapours: A tentative strategy for detoxification. Food Control 2020, 118, 107744. [CrossRef]

27. Şengül, Ü. Comparing determination methods of detection and quantification limits for aflatoxin analysis in Hazelnut. J. Food Drug Anal. 2016, 24, 56-62. [CrossRef]

28. Bryła, M.; Waśkiewicz, A.; Podolska, G.; Szymczyk, K.; Jędrzejczak, R.; Damaziak, K.; Sułek, A. Occurrence of 26 mycotoxins in the grain of cereals cultivated in Poland. Toxins 2016, 8, 160. [CrossRef]

29. Liu, Y.; Lu, Y.; Wang, L.; Chang, F.; Yang, L. Occurrence of deoxynivalenol in wheat, Hebei Province, China. Food Chem. 2016, 197, 1271-1274. [CrossRef]

30. Ji, F.; Xu, J.; Liu, X.; Yin, X.; Shi, J. Natural occurrence of deoxynivalenol and zearalenone in wheat from Jiangsu province, China. Food Chem. 2014, 15, 393-397. [CrossRef]

31. Obonyo, M.A.; Salano, E.N. Perennial and seasonal contamination of maize by aflatoxins in eastern Kenya. Int. J. Food Contam. 2018. [CrossRef]

32. Paterson, R.R.M.; Lima, N. How will climate change affect mycotoxins in food? Food Res. Int. 2010, 43, 1902-1914. [CrossRef]

33. Kamala, A.; Ortiz, J.; Kimanya, M.; Haesaert, G.; Donoso, S.; Tiisekwa, B.; Meulenaer, B.D. Multiple mycotoxin co-occurrence in maize grown in three agro-ecological zones of Tanzania. Food Control 2015, 54, 208-215. [CrossRef]

34. Abia, W.; Warth, A.; Sulyok, M.; Krska, R.; Tchana, A.N.; Njobeh, P.B. Determination of multi-mycotoxin occurrence in cereals, nuts and their products in Cameroon by liquid chromatography tandem mass spectrometry (LCMS/MS). Food Control 2013, 31, 438-453. [CrossRef]

35. Cirillo, T.; Ritieni, A.; Galvano, F.; Cocchieri, R.A. Natural co-occurrence of deoxynivalenol and fumonisins B1 and B2 in Italian marketed foodstuffs. Food Addit. Contam. 2003, 20, 566-571. [CrossRef] [PubMed]

36. Pleadin, J.; Sokolović, M.; Perši, N.; Zadravec, M.; Jaki, V.; Vulić, A. Contamination of maize with deoxynivalenol and zearalenone in Croatia. Food Control 2012, 28, 94-98. [CrossRef]

37. Setyabudi, F.M.C.S.; Nuryono, N.; Wedhastri, S.; Mayer, H.K.; Razzazi-Fazeli, E. Limited survey of deoxynivalenol occurrence in maize kernels and maizeproducts collected from Indonesian retail market. Food Control 2012, 24, 123-127. [CrossRef]

38. Martos, P.; Thompson, W.; Diaz, G. Multiresidue mycotoxin analysis in wheat, barley, oats, rye and maize grain by high-performance liquid chromatography tandem mass spectrometry. World Mycotox J. 2010, 3, 205-223. [CrossRef]

39. Kuiper-Goodman, T. Approaches to the risk analysis of mycotoxins in the food supply. In Proceedings of the Food and Nutrition div. Eng Joint FAO/WHO/UNEP International Conference on Mycotoxins, Tunis, Tunisia, 3-6 March 1999; Volume 23, pp. 10-16.

40. Raad, F.; Nasreddine, L.; Hilan, C.; Bartosik, M.; Parent-Massin, D. Dietary exposure to aflatoxins, ochratoxin A and deoxynivalenol from a total diet study in an adult urban Lebanese population. Food Chem. Toxicol. 2014, 73, 35-43. [CrossRef]

41. Cano-Sancho, G.; Ramos, V.; Marín, S.; Sanchis, V. Micotoxinas. Estudio de dieta Total en Cataluña 2008-2009; Generalitat de Cataluña: Barcelona, Spain, 2012; pp. 135-140.

42. Ostry, V.; Dofkova, M.; Blahova, J.; Malir, F.; Kavrik, R.; Rehurkova, I.; Ruprich, J. Dietary exposure assessment of sum deoxynivalenol forms, sum T-2/HT-2 toxins and zearalenone from cereal-based foods and beer. Food Chem. Toxicol. 2020, 139, 111280. [CrossRef] [PubMed]

43. Stanciu, O.; Juan, C.; Miere, D.; Berrada, H.; Loghin, F.; Mañes, J. First study on trichothecene and zearalenone exposure of the Romanian population through wheat based products consumption. Food Chem. Toxicol. 2018, 121, 336-342. [CrossRef] [PubMed]

44. Assunção, R.; Martins, C.; Vasco, E.; Jager, A.; Oliveira, C.; Cunha, S.C.; Fernandes, J.O.; Nunes, B.; Loureiro, S.; Alvito, P. Portuguese children dietary exposure to multiple mycotoxins-An overview of risk assessment under MYCOMIX project. Food Chem. Toxicol. 2018, 118, 399-408. [CrossRef] [PubMed]

(C) 2020 by the authors. Licensee MDPI, Basel, Switzerland. This article is an open access article distributed under the terms and conditions of the Creative Commons Attribution (CC BY) license (http://creativecommons.org/licenses/by/4.0/). 